\title{
DAMPAK FAKTOR VOLUME PENAWARAN SAHAM TERHADAP RISIKO SISTEMATIS : PENERAPAN DENGAN REGRESI DATA PANEL METODE COMMON EFFECT (STUDI PADA SAHAM-SAHAM DALAM JII DI BURSA EFEK INDONESIA PERIODE JANUARI - APRIL 2020) KAJIAN STUDI PADA KONDISI PANDEMI VIRUS COVID-19
}

\author{
Sunaryo \\ Fakultas Ekonomi dan Bisnis Universitas Islam As-Syafi'iyah \\ Sunaryo56@gmail.com
}

\begin{abstract}
This study aims to determine the impact of Stock Offer Volume on Systematic Risk. This study uses the object of stocks in the JII (Jakarta Islamic Index) group which is listed on the Indonesia Stock Exchange (BEI) for the period January to April 2020 with a saturated sample (census sampling) as a method. There are 20 stocks selected as samples. The method of analysis of this research is panel data regression with the common effect method. The study found that the results of the volume of stock offerings have a positive and significant effect on systematic risk.
\end{abstract}

Keywords : Supply Volume Stock and Systematic Risk

\begin{abstract}
Abstrak. Penelitian ini bertujuan untuk mengetahui dampak Volume Penawaran Saham terhadap Risiko Sistematis. Penelitian ini menggunakan obyek saham-saham dalam kelompok JII (Jakarta Islamic Index) yang terdaftar di Bursa Efek Indonesia (BEI) untuk periode Januari hingga April 2020 dengan sampel jenuh (sensus sampling) sebagai metode. Terdapat 20 saham yang dipilih sebagai sampel. Metode analisis penelitian ini adalah regresi data panel dengan metode common effect. Penelitian menemukan hasil volume penawaran saham berpengaruh positif dan signifikan terhadap risiko sistematis.
\end{abstract}

Kata kunci: Volume Penawaran Saham dan Risiko Sistematis

\section{A. PENDAHULUAN}

\section{Latar Belakang Penelitian}

Berdasarkan sumber Suara.com (04/04/2020) yang ditulis oleh Yasinta Rahmawati, virus corona baru atau Covid-19 telah menyebar ke hampir setiap negara di dunia sejak pertama kali muncul di China pada awal tahun 2020, penyakit ini sudah mulai menyerang di Eropa, Amerika Serikat dan Asia Tenggara dan mulai menimbulkan kekacauan di Afrika dan Amerika Selatan.

CNBC Indonesia mengutip WHO, virus corona termasuk keluarga besar virus yang dapat menimbulkan penyakit pada manusia atau hewan. Efek virus corona terhadap manusia terlihat dari gejala infeksi pernafasan yang didahului oleh flu biasa sampai menjadi penyakit kronis seperti Middle East Respiratory Syndrome (MERS), dan Severe Acute Respiratory Syndrme (SARS). 
Hari Jum'at tanggal 3 April 2020 pukul 19.15 Worldometers mencatat menyebarnya virus corona menyebabkan yang terinfeksi 1.033.210 kasus dan kematian sebanyak 54.442. Sedangkan John Hopkins mencatat yang terinfeksi 1.030 .628 kasus dan kematian sebanyak 54.137. Saat ini kasus terbanyak terjadi di Amerika Serikat sebanyak dengan 245.573 kasus, di New York mencatat terbanyak kematian 1.562 orang.

Awal bulan Maret 2020 virus corona mulai merebak di Indonesia, dan pada bulan tersebut bersamaan mulai dilakukan pencegahan virus corona (virus covid 19). Virus corona yang merebak di Indonesia bukan hanya mempunyai dampak terhadap kesehatan manusia, namun tanpa kecuali juga berdampak terhadap perekonomian Indonesia. Berdasarkan sumber dari CNN Indonesia, Menteri Keuangan Republik Indonesia Sri Mulyani mengungkapkan, pertumbuhan ekonomi Indonesia diproyeksi dapat dicapai $2,3 \%$, dan terburuk dapat mencapai negatif hingga $0,4 \%$. Pertumbuhan ekonomi yang menurun tersebut antara lain karena penurunan konsumsi dan investasi dari rumah tangga maupun pemerintah.

Sektor pasar keuangan dan pasar modal juga tidak lepas dari dampak virus corona, hal ini terlihat meningkatnya kurs rupiah terhadap dollar Amerika Serikat yang cukup tajam mencapai Rp 16.000/\$US. Di Bursa Efek Indonesia (BEI) Indeks Harga Saham Gabungan (IHSG) menunjukkan penurunan yang signifikan dalam beberapa minggu terakhir bulan Maret 2020. Tabel berikut ini memberikan gambaran pergerakan Kurs dan IHSG selama pandemi Virus Covid 19.

Tabel 1. Pergerakan Kurs Tengah BI Rp/USD Januari - April 2020

\begin{tabular}{ccccc}
\hline & \multicolumn{4}{c}{ Bulan tahun 2020 } \\
\cline { 2 - 5 } & Januari & Februari & Maret & April \\
\hline Kurs (Rp) & 13.655 & 14.234 & 16.367 & 15.157 \\
\hline Sumber : Bank Indonesia & & &
\end{tabular}

Tergambar dari tabel 1 di atas, kurs rupiah terhadap US dolar dari bulan Januari sampai dengan bulan Maret 2020 peningkatannya cukup tajam. Walaupun bulan April 2020 terjadi penurunan dibandingkan Maret 2020, namun besarnya kurs masih dalam kategori cukup tinggi. Kurs yang meningkat pada bulan Januari sampai dengan Maret 2020 terjadi seiring merebaknya pandemi Virus Covid 19 di Indonesia. Selanjutnya berikut ini disajikan tabel 2 yang menggambarkan pergerakan kinerja BEI yang dilihat dari indikator IHSG.

Tabel 2. Pergerakan IHSG Januari - April 2020

\begin{tabular}{ccccc}
\hline & \multicolumn{4}{c}{ Bulan tahun 2020 } \\
\cline { 2 - 5 } & Januari & Februari & Maret & April \\
\hline IHSG & $6.057,59$ & $5.452,70$ & $4.538,93$ & $4.642,47$ \\
\hline Sumber: BEI & & & &
\end{tabular}

Tergambar dari tabel 1 di atas, Indeks Harga Saham Gabungan (IHSG) dari bulan Januari sampai dengan Maret 2020 menurunnya cukup tajam. Walaupun bulan April 2020 terjadi peningkatan dibandingkan Maret 2020, namun tingkat IHSG masih dalam kategori rendah. IHSG yang menurun pada bulan Januari sampai dengan bulan Maret 2020 terjadi seiring merebaknya pandemi Virus Covid 19 di Indonesia. 
Jakarta Islamic Index (JII) di Bursa Efek Indonesia (BEI) yang merupakan sahamsaham yang berbasis syariah tidak lepas kena dampak dari merebaknya virus corona. Hal ini pergerakan disajikan pada tabel 3 berikut ini.

Tabel 3. Pergerakan JII Januari - April 2020

\begin{tabular}{ccccc}
\hline & \multicolumn{4}{c}{ Bulan tahun 2020 } \\
\cline { 2 - 5 } & Januari & Februari & Maret & April \\
\hline JII & 642.804 & 565.007 & 476.388 & 542.496 \\
\hline Sumber : BEI & & & &
\end{tabular}

Tergambar dari tabel 3 di atas JII menurun cukup tajam dari bulan Januari sampai dengan bulan Maret 2020 menurun cukup signifikan, walaupun bulan April 2020 meningkat, namun tidak begitu berarti dibandingkan Maret. Penurunan JII pada bulanbulan tersebut seiring dengan merebaknya selama pandemi Virus Covid 19 di Indonesia, dan menurunnya JII pada bulan-bulan tersebut bersamaan merebaknya pandemi Virus Covid 19 di Indonesia.

CNBC Indonesia mengutip (07/04/2020), Otoritas Jasa Keuangan (OJK) mengatakan merosotnya IHSG yang cukup signifikan sampai pada tingkat terendah dibandingkan yang pernah terjadi dampak dari penyebaran virus corona. Wimboh Santoso selaku Ketua Dewan Komisioner menyatakan penurunan indeks saham mencapai 23,3\% mulai Januari 2020, walapun pada penutupan perdagangan IHSG Senin (6/4/2020) menguat sebesar 4,07 persen ke posisi 4.811, dan sudah menunjukkan mulai hijau dan mulai rebound (balik arah) dalam beberapa hari terakhir.

Lebih lanjut Wimboh mengatakan, sejak Januari 2020 pemodal luar negeri atau pemodal asing telah menjual sahamnya di bursa dengan nilai Rp11,3 triliun, sementara di pasar Surat Berharga Negara (SBN) pemodal asing telah mencairkan dana sebesar Rp129,2 triliun.

Rully R. Ramli (Kompas.com) mengutip pendapat OJK (12/03/2020), sentimen negatif sebagai salah satu penyebab penekan kinerja ekonomi global sejak Januari 2020 adalah karena virus corona. Sentimen negatif ini penyebab pemodal asing mencairkan dananya di pasar saham yang akhirnya menyebabkan penawaran volume saham yang berlebihan. Secara teoritis seperti yang diungkap oleh Umam dan Sutanto (2017), penawaran volume saham lebih besar dibandingkan volume permintaan saham, maka menyebabkan menurunnya harga saham.

Harga saham yang turun tajam sebagaimana dicerminkan pada IHSG (tabel 2) dan JII (tabel 3) di atas yang diakibatkan terjadi penawaran saham yang berlebihan, menyebabkan volatilitas harga saham meningkat yang cukup tajam, pada kondisi ini berakbat meningkatnya risiko sistematis investasi pada saham, hal ini tergambar di tabel 4 bawah ini.

Tabel 4. Pergerakan Risiko Sistematis Saham Dalam Kelompok JII di Bursa Efek Indonesia Bulan Januari -April 2020

\begin{tabular}{ccccc}
\hline & \multicolumn{4}{c}{ Bulan tahun 2020 } \\
\cline { 2 - 5 } & Januari & Februari & Maret & April \\
\hline Rata-rata Beta & 1.29502 & 1.34063 & 1.32437 & 1.36421 \\
\hline Sumber : Pefindo di olah & & & &
\end{tabular}


Tergambar dari tabel 4 di atas rata-rata risiko sistematis (beta) saham dalam kelompok JII di BEI cenderung meningkat dari bulan Januari hingga April 2020. Peningkatan risiko sistematis tersebut seiring merebaknya Virus Covid 19 di Indonesia.

Secara teoritis Panetta et al (2006) mengemukakan salah satu faktor penentu volatilitas (risiko sistematis) adalah kejadian luar biasa (shock). Kejadian luar biasa yang saat ini dialami di Indonesia adalah merebaknya Virus Covid 19 yang menimbulkan sentimen negatif bagi investor, sehingga mendorong investor mencairkan atau menjual sahamnya, sehingga menyebabkan terjadi peningkatan penawaran volume saham.

Secara teori harga saham di pasar modal yang fluktuasi menurut Umam dan Sutanto (2017) dipengaruhi oleh faktor permintaan (demand) dan penawaran (supply). Sesuai dengan hukum permintaan dimana meningkatnya minat pemodal untuk membeli (permintaan) saham, semakin tinggi harga saham tersebut. Kebalikannya meningkatnya.

Faktor yang dapat memengaruhi kekuatan permintaan dan penawaran yang dapat mengakibatkan volatilitas harga saham menurut Beaver, Kettler, dan Scholes dalam Jogiyanto (2017), yaitu faktor fundamental internal, seperti dividen payout, asset growth, leverage, liquidity, asset size, earning variability dan accounting beta.

Menurut Panetta et al. (2006) yang mengutip Tim Studi Volatilitas Pasar Modal Indonesia dan Perekonomian Dunia, variabel yang memengaruhi volatilitas dikategorikan dalam empat variabel yakni sektor riil, sektor finansial, kejadian luar biasa (shock), serta kebijakan moneter.

Menurut Sunariyah (2013) yang menyebabkan risiko saham atau risiko sistematis yaitu faktor makro ekonomi.

Penelitian terdahulu yang telah melakukan riset yang berkaitan antara volume perdagangan saham dengan risiko sistematis atau volatalitas harga saham seperti Tara (2018), Rizqin dan Mohammad (2017), Dewi \& Suaryana (2016), Sandrasari (2010) menghasilkan temuan volume perdagangan saham berdampak positif dan signifikan terhadap volatilitas harga saham. Laura and Karlis (2013) menghasilkan temuan frekuensi perdagangan saham mempunyai hubungan yang tinggi dengan risiko sistematis di Bursa Efek Eropa. Nidal (2008) menghasilkan temuan volume perdagangan mempunyai dampak yang signifikan terhadap harga saham untuk seluruh selected markets.

Namun Ni Wayan dan Gayatri (2018), Syarifah et al (2018) dan Rahmawati (2017) menghasilkan temuan volume perdagangan saham berpengaruh tidak signifikan terhadap volatilitas harga saham.

Dari latar belakang di atas memberikan gambaran risiko sistematis (beta) yang menujukkan peningkatan, dan gambaran terdapat perbedaan hasil penelitian terdahulu, oleh karena itu penelitian ini mencoba analisis variabel penyebab yang berpengaruh terhadap risiko sistematis saham-saham dalam JII, dan sekaligus melakukan pengujian lanjutan untuk menemukan konsistensi dari temuan penelitian terdahulu yang berbeda hasilnya.

\section{Perumusan Masalah}

Berdasarkan gambaran latar belakang penelitian di atas, dapat diidentifikasi masalah penelitian, dimana terdapat variabel yang berpengaruh terhadap risiko sistematis seperti dividen payout, asset growth, leverage, liquidity, asset size, earning variability dan accounting beta, sektor riil, faktor sektor finansial, kejadian luar biasa (shock), serta kebijakan moneter. Dan variabel yang berpengaruh langsung seperti permintaan dan penawaran saham. 
Pada penelitian ini penawaran volume saham menjadi variabel pilihan sebagai faktor yang langsung berhubungan dengan risiko sistematis (volatilitas) dan faktor kejadian luar biasa (shock). Pemilihan faktor tersebut didasarkan pertimbangan pada fenomena dari pernyataan praktisi pasar modal, dimana salah satu pemicu sentimen negatif adalah virus corona yang menyebabkan investor melepas sahamnya dibursa.

Berlandaskan pembatasan masalah penelitian, fenomena meningkatnya risiko sistematis dan perbedaan hasil penelitian terdahulu, dalam penelitian ini mengajukan pertanyaan : Apakah volume penawaran saham berpengaruh terhadap risiko sistematis dalam kelompok saham-saham JII pada kondisi pandemi virus corona?

\section{Tujuan Penelitian}

Penelitian ini bertujuan untuk menganalisis, memperoleh bukti empiris, dan menjelaskan pengaruh volume penawaran saham terhadap risiko sistematis pada sahamsaham dalam kelompok JII pada kondisi pandemi virus corona.

\section{Manfaat Penelitian}

Manfaat yang ingin dicapai dari penelitian ini :

(1) Manfaat Praktis

Diharapkan hasil penelitian ini dapat dijadikan referensi bagi pemodal di Pasar Modal dalam kegiatan investasi saham yang berbasis syariah.

(2) Manfaat Untuk Akademik

Bagi akademik, diharapkan hasil penelitian ini dapat dijadikan pembuktian empiris mengenai pengaruh volume penawaran saham terhadap risiko sistematis.

\section{B. TINJAUAN PUSTAKA DAN HIPOTESIS}

\section{Landasan Teori}

\subsection{Jakarta Islamic Index}

Saham-saham syariah di tercatat BEI dapat dijadikan alternatif bagi pemodal yang ingin menerapan syariat Islam dalam kegiatan berinvestasi. Berdasarkan peraturan dan perundangan OJK yang termasuk kategori saham berbasis syariah pengakuannya di pasar modal Indonesia terdapat dua jenis saham syariah. Menurut peraturan OJK Nomor 35/POJK.04/2017 tentang Kriteria dan Penerbitan Daftar Efek Syariah, saham yang dapat memenuhi kriteria seleksi atau syarat saham syariah, yaitu:

- Pertama, saham yang dapat memenuhi kriteria seleksi saham syariah berdasarkan adalah peraturan OJK Nomor 35/POJK.04/2017 tentang Kriteria dan Penerbitan Daftar Efek Syariah,

- Kedua adalah kategori sebagai saham yang dicatat saham syariah oleh emiten atau perusahan publik syariah atas dasar peraturan OJK no. 17/POJK.04/2015.

Jakarta Islamic Index (JII) digunakan sebagai indikator untuk mengamati pergerakan indeks saham syariah. Pada tanggal 3 Juli 2000 untuk pertama kalinya JII digunakan sebagai indeks saham yang berbasis syariah di pasar modal Indonesia.

Saham dalam kelompok JII terdiri dari 30 saham syariah paling likuid yang tercatat di BEI. BEI berwenang menetapkan menseleksi saham syariah yang menjadi konstituen JII sebagai berikut (sumber Fahmi, 2014:311): 
- Sekurang-kurangnya 3 bulan terakhir saham yang dipilih sudah tercatat, terkecuali saham dalam kategori 10 kapitalisasi besar.

- Tercatat dilaporan keuangan tahunan atau semester, Rasio hutang terhadap Aktiva tidak lebih besar dari $90 \%$.

- Kriteria 1 dan 2 terpenuhi, selanjutnya dipilih 60 saham yang diurut dari rata-rata kapitalisasi pasar terbesar selama satu tahun terakhir.

- Dari 60 saham terpilih, diseleksi lagi menjadi 30 saham, pemilihan diurut dari tingkat likuiditas rata-rata nilai perdagangan regular selama tahun terakhir.

Dalam rangka untuk mendapatkan imbal hasil bagi pemodal maupun calon pemodal yang menanamkan dananya di bursa, pergerakan JII dapat digunakan sebagai acuan. Kebanyakan pemodal yang berinvestasi saham di bursa yang utama menginginkan return dalam bentuk capital gain.

\subsection{Volume Penawaran Saham}

Penawaran penjualan saham oleh investor adalah jumlah sekuritas (saham) yang ingin dijual pada berbagai tingkat harga (Sharpe et al : 2006). Ang (2010) mengemukakan, pergerakan volume perdagangan saham merupakan cermin dari reaksi antara permintaan dan penawaran yang mencertminkan tingkah laku pemodal. Lebih lanjut Ang (2010) mengemukakan meningkatnya volume perdagangan saham, maka kondisi pasar dapat dikatakan menguat, demikian pula sebaliknya (Ang, 2010). Istilah populernya di bursa menguat adalah Bullish, sedangkan melemah istilah populernya Bearish.

Analisis teknikal digunakan untuk memprediksi trend permintaan dan penawaran saham. Menurut Tandelilin (2010) yang mengutip Meyer (1989), studi mengenai sekuritas atau pasar secara keseluruhan berdasarkan permintaan dan penawaran disebut analisis teknikal. Analisis teknikal menggunakan analisis berbentuk chart (grafik) untuk meramalkan trend harga masa depan atas dasar data historis harga dan aktivitas volume transaksi diolah (Tandelilin: 2010). Menurut Tandelilin (2010) yang mengutip Levy (1966), dalam analisis teknikal adalah trend perubahan dan nilai pasar dapat berubah dengan asumsi salah satunya adalah karena hubungan permintaan dan penawaran.

Menurut Tandelilin (2010) yang mengutip Levy (1966), permintaan dan penawaran saham dipengaruhi oleh variabel ekonomi dan variabel fundamental serta faktorfaktor opini yang beredar, mood pemodal, dan ramalan-ramalan pemodal.

\subsection{Risiko Sistematis}

Keown et al. (2004:206) berpendapat : "risiko sistematis adalah risiko yang berhubungan dengan pasar, dimana untuk menurunkan risiko tersebut yang tidak dapat didiversifikasikan". Fahmi (2014:461) berpendapat: "risiko sistematis (systematic risk) adalah risiko yang tidak dapat didiversifikasikan atau dengan perkataan lain risiko yang sifatnya berpengaruh secara menyeluruh, sebagai contohnya krisis moneter di tahun 1997, dan systematic risk disebut market risk atau risiko umum". Jogiyanto (2017:474) berpendapat: "pengukur risiko sistematik dari suatu sekuritas atau portofolio relatif terhadap risiko pasar adalah beta". Lebih lanjut 
Jogiyanto (2017:463) mengemukakan, pengukur volatilitas (volatility) return suatu sekuritas (saham) atau return portofolio terhadap return pasar adalah beta.

Risiko sistematis (volatilitas) dipengaruhi oleh pergerakan harga saham di bursa. Pergerakan (volatilitas) harga saham dipengaruhi oleh reaksi permintaan (demand) dan penawaran (supply) (Umam dan Sutanto: 2017).

Lebih lanjut Umam dan Sutanto (2017) mengemukakan, harga saham yang meningkat karena semakin banyak pemodal yang membeli saham tersebut, demikian sebaliknya. Dengan demikian naik turunnya harga saham dipengaruhi oleh permintaan dan penawaran saham. Harga saham yang naik dan turun menurut Jogiyanto (2017) merupakan volitilitas atau risiko sistematis, "volatilitas adalah fluktuasi dari return-return suatu sekuritas atau portofolio dalam sutau periode tertentu".

Faktor yang memengaruhi permintaan dan penawaran saham yang akhirnya berdampak terhadap risiko sistematis, menurut:

- Husnan (2005) variabel-variabel yang dapat memengaruhi nilai beta ((risiko sistematis) adalah:

(1) Cyclicality. Variabel ini memberikan gambaran besarnya suatu perusahaan dipengaruhi oleh konjungtur perekonomian. Apabila perekonomian membaik kondisnya, maka dampak positif akan dinikmati oleh semua perusahaan. Sebaliknya pada saat kondisi resesi, maka dampak negatif semua perusahaan akan merasakannya.

(2) Operating leverage. Variabel ini memberikan gambaran besar biaya tetap yang ditanggung oleh perusahaan. Biaya tetap yang semakin maka semakin tinggi operating leverage, dan akan diikuti beta cenderung tinggi.

(3) Financial leverage. Variabel ini memberikan gambaran besarnya hutang perusahaan. Porsi hutang yang semakin tinggi maka semakin tinggi financial leverage, dan dan akan diikuti beta cenderung tinggi.

- Menurut Sunariyah (2013) variabel makro dapat memengaruhi risiko saham disebut sebagai risiko sistematis.

- Schwert (1989) mengemukakan, faktor makro maupun mikro dapat memengaruhi tingkat volatilitas. Sedangkan Panetta et al. (2006) mengemukakan, tingkat volatilitas dipengaruhi oleh faktor sektor riil, faktor sektor finansial, kejadian luar biasa (shock), serta kebijakan moneter.

- Sukamulja (2011) yang dikutip oleh Tim Studi Volatilitas Pasar Modal Indonesia dan Perekonomian Dunia, Laporan Studi Volatilitas Pasar Modal Indonesia dan Perekonomian Dunia, mengajukan proposisi bahwa volatilitas return saham di pasar modal Indonesia dipengaruhi oleh faktor-faktor:

1) Kesalahan penentuan harga (mispricing) oleh investor karena tidak memperoleh informasi yang cukup memadai;

2) Terhadap informasi yang diperoleh investor, berearksi yang berlebihan

3) Investor cenderung melakukan motif spekulasi dalam berinvestasi;

4) Investor domestik yang cenderung mengekor pola transaksi investor asing (herding behavior);

5) Trading noise seperti rekomendasi analis, rumor, dan hari libur bursa; 
6) Ketersediaan data aksesibilitas data;

7) Faktor-faktor ekonomi dan non ekonomi dari luar negeri.

Berdasarkan telaah teori seperti di uraikan di atas dapat disimpulkan bahwa kekuatan permintaan (demand) dan penawaran (supply) akan menentukan volatilitas harga saham. Volatilitas akan menimulkan risiko sistematis. Risiko sistematis ditentukan oleh faktor sebagaimana dikemukakan oleh Husnan (2005), Sunariyah (20130) Schwert, (1989), Panetta et al. (2006) dan Sukamulja (2011). Jadi dalam analisis hubungan permintaan dan penawaran saham dengan risiko sistematis tidak terlepas dari analisis faktor yang menentukan risiko sistematis.

\section{Kerangka Pemikiran Teoritis dan Perumusan Hipotesis}

Pengaruh Volume Penawaran Saham terhadap Risiko Sistematis. Ang (2010) mengemukakan, frekuensi perdagangan yang meningkat akan memengaruhi aktivitas pasar dalam perdagangan, dan akan berakibat harga saham berfluktuasi naik atau turun, sehingga berdampak meningkatnya volatilitas harga saham. Chan dan Fong (2000) juga mengungkapkan, apabila volume perdagangan meningkat maka volatilitasnya juga akan naik.

Volume perdagangan saham menggambarkan permintaan dan penawaran saham, dimana harga saham akan meningkat jika suatu saham berlebihan permintaannya dibandingkan penawaran, dan akan turun jika terjadi penawaran yang berlebihan (Umam dan Sutanto (2017:176-177). Syamsir (2006) menyatakan :"dalam analisis teknikal asumsi dasarnya adalah bahwa harga sangat ditentukan oleh keseimbangan antara supply dan demand, dan jika terjadi ekses supply (kelebihan supply atas demand), maka harga akan jatuh dan demikian sebaliknya." Apabila terjadi penawaran suatu saham yang lebih besar dibandingkan permintaannya maka harga saham akan cenderung menurun dan akan terjadi fluktuasi terhadap harga saham tersebut.

Fluktuasinya harga saham yang disebabkan oleh permintaan dan penawaran saham seperti yang diungkap Panetta et al (2006) salah satu faktornya adalah kejadian luar biasa (shock). Kejadian luar biasa yang saat ini dialami di Indonesia adalah merebaknya Virus Covid 19 yang menimbulkan sentimen negatif bagi investor, sehingga mendorong investor mencairkan atau menjual sahamnya, sehingga akan menyebabkan penawaran saham yang berlebihan.

Penelitian sebelumnya seperti Tara (2018), Rizqin dan Mohammad (2017), Dewi dan Suaryana (2016), Sandrasari (2010) menghasilkan temuan volume perdagangan saham berpengaruh positif dan signifikan terhadap volatilitas harga saham. Berdasarkan telaah teori dan temuan penelitian sebelumnya tersebut, rumusan hipotesis dalam penelitian ini:

$\mathrm{H}$ : Volume penawaran saham berpengaruh positif terhadap risiko sistematis. 


\section{KERANGKA PEMIKIRAN TEORITIS}

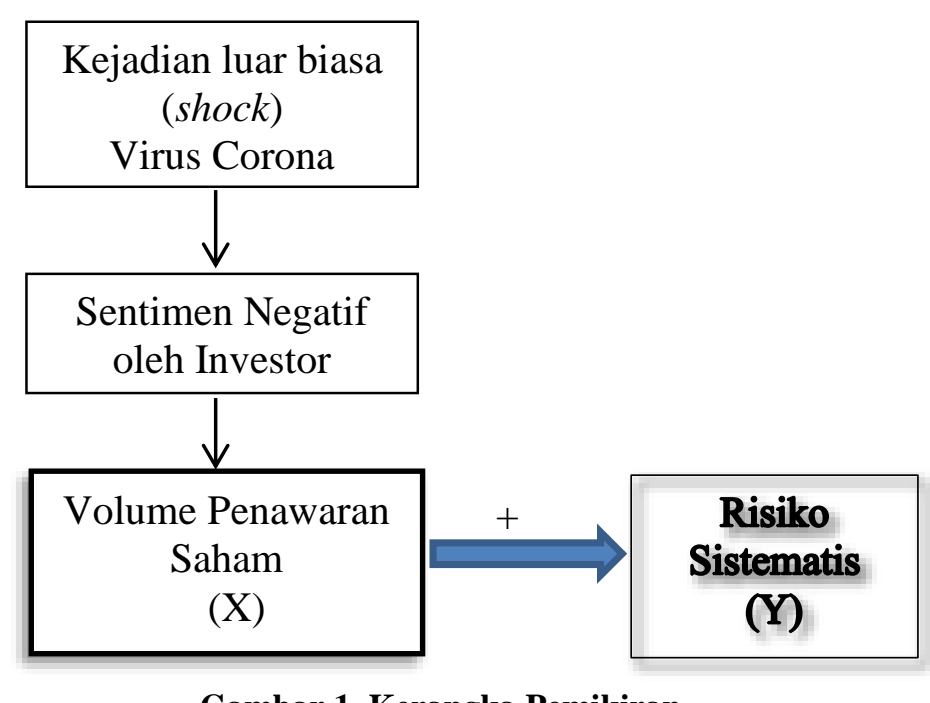

Gambar 1. Kerangka Pemikiran

\section{METODE PENELITIAN}

Saham-saham syariah yang masuk dalam kelompok JII (Jakarta Islamic Index) sebagai populasi penelitian ini adalah yang masuk dalam daftar lampiran pengumuman BEI No Peng-00555/BEI.POP/11-2019 untuk Periode: Desember 2019 - Mei 2020. Sedangkan yang digunakan sebagai sampel adalah sampel jenuh (sensus sampling), dan daftar nama sampel saham disajikan pada tabel 4 di bawah ini. 
Tabel 4. Daftar Nama Saham Dalam Kelompok JII

\begin{tabular}{|c|c|l|l|}
\hline No & Kode Saham & \multicolumn{1}{|c|}{ Nama Saham } & \multicolumn{1}{|c|}{ Kategori Sektor } \\
\hline 1 & ADRO & Adaro Energy Tbk. & Mining \\
2 & AKRA & AKR Corporindo Tbk. & Trade, Service \& Investment \\
3 & ANTM & Aneka Tambang (Persero) Tbk & Mining \\
4 & ASII & Astra International Tbk. & Misc Industry \\
5 & BRPT & Barito Pacific Tbk. & Chemical Industry \\
6 & BSDE & Bumi Serpong Damai Tbk. & Property \& Construction \\
7 & BTPS & Bank Tabungan Pensiunan National Syariah Tbk & Finance \\
8 & CPIN & Charoen Pokphand Indonesia Tbk & Chemical Industry \\
9 & CTRA & Ciputra Development Tbk. & Property \& Construction \\
10 & ERAA & Erajaya Swasembada Tbk. & Trade, Service \& Investment \\
11 & EXCL & XL Axiata Tbk. & Infrastructure \& Transportation \\
12 & ICBP & Indofood CBP Sukses Makmur Tbk & Consumer Goods \\
13 & INCO & Vale Indonesia Tbk & Mining \\
14 & INDF & Indofood Sukses Makmur Tbk. & Consumer Goods \\
15 & INTP & Indocement Tunggal Prakarsa Tbk. & Chemical Industry \\
16 & ITMG & Indo Tambangraya Megah Tbk. & Mining \\
17 & JPFA & JAPFA Comfeed Indonesia Tbk & Chemical Industry \\
18 & JSMR & Jasa Marga (Persero) Tbk. & Infrastructure \& Transportation \\
19 & KLBF & Kalbe Farma Tbk. & Consumer Goods \\
20 & LPPF & Matahari Department Store Tbk. & Trade, Service \& Investment \\
\hline
\end{tabular}

Dalam penelitian ini menggunakan data sekunder volume penawaran dan beta akhir bulan, mulai Januari hingga April 2020.

Data penawaran saham diperoleh dari PT Bursa Efek Indonesia, IHSG diperoleh dari Investing.com, dan beta diperoleh dari Pefindo.

Tabel 5. Variabel dan Definisi Operasional

\begin{tabular}{|c|c|c|c|}
\hline Variabel & Konsep & Operasional Variabel & Skala \\
\hline $\begin{array}{l}\text { Volume } \\
\text { Penawaran Saham }\end{array}$ & $\begin{array}{l}\text { Volume penawaran saham } \\
\text { adalah jumlah sekuritas (saham) } \\
\text { yang ingin dijual pada berbagai } \\
\text { tingkat harga }\end{array}$ & $\begin{array}{l}\text { Volume penawaran saham } \\
\text { adalah jumlah lot penawaran } \\
\text { saham }\end{array}$ & Rasio \\
\hline Risiko Sistematis & $\begin{array}{l}\text { Risiko sistematis adalah risiko } \\
\text { yang berhubungan dengan pasar, } \\
\text { dimana untuk menurunkan risiko } \\
\text { tersebut yang tidak dapat } \\
\text { didiversifikasikan }\end{array}$ & $\begin{array}{l}\begin{array}{l}\text { Pengukur risiko sistematik } \\
\text { adalah Beta }\end{array} \\
\beta \mathrm{i}=\frac{\sigma \mathrm{iM}}{\sigma^{2} \mathrm{M}} \\
\sigma \mathrm{iM}=\text { kovarian return antara } \\
\text { sekuritas ke-i dengan return pasar } \\
\sigma^{2} \mathrm{M}=\text { varian return pasar } \\
\text { Dalam satuan indeks }\end{array}$ & Rasio \\
\hline
\end{tabular}


Dalam penelitian ini menggunakan metode analisis regresi data panel dengan metode common effect. Penerapan metode common effect yang mengasumsikan bahwa perilaku data antar indivdu (saham-saham) sama dalam berbagai kurun waktu (Widarjono, 2012) dengan formula berikut:

$$
Y_{\text {it }}=\beta_{0}+\beta X_{i t}+\varepsilon_{\text {it }}
$$

Keterangan:

$\beta_{0}=$ Konstanta atau intersep di asumsikan tidak terdapat perbedaan antar individu/unit

$\mathrm{Y}_{\text {it }}=$ Risiko Sistematis; $\mathrm{X}=$ Volume Penawaran Saham

$\mathrm{i}=$ saham-saham, $\mathrm{t}=$ periode, $\varepsilon=$ Error/variabel gangguan

\section{HASIL PENELITIAN DAN PEMBAHASAN}

\section{Hasil Penelitian}

\section{Tabel 6. Output Regresi Data Panel Metode Common Effect}

Dependent Variable: BETA

Method: Panel EGLS (Cross-section weights)

Sample: 2020M01 2020M04

Periods included: 4

Cross-sections included: 20

Total panel (balanced) observations: 80

\begin{tabular}{|c|c|c|c|c|}
\hline Variable & Coefficient & Std. Error & t-Statistic & Prob. \\
\hline C & 0.876693 & 0.083395 & 10.51259 & 0.0000 \\
\hline VOLUME & 0.038352 & 0.007127 & 5.381428 & 0.0000 \\
\hline \multicolumn{5}{|c|}{ Weighted Statistics } \\
\hline R-squared & 0.270754 & \multirow{5}{*}{\multicolumn{2}{|c|}{ Durbin-Watson stat }} & 0.705158 \\
\hline Adjusted R-squared & 0.261405 & & & \\
\hline S.E. of regression & 0.320063 & & & \\
\hline F-statistic & 28.95976 & & & \\
\hline Prob(F-statistic) & 0.000001 & & & \\
\hline
\end{tabular}

Sumber: Output Program Eviews9

Dari Tabel 6 di atas dapat disusun bersamaan model regresi data panel metode Common Effect sebagai berikut:

$Y=0.876693+0.038352 X$

\section{Koefisien Determinasi $\left(\mathbf{R}^{2}\right)$}

Seperti terlihat pada Tabel 6 nilai adjusted R-squared sebesar 0.2614 atau 26.14\%, yang berarti $26.14 \%$ variasi Beta (Risiko Sistematis/Y) dapat diterangkan oleh variasi variabel bebas X (Volume Penawaran Saham), dan sisanya sebesar $73.86 \%$ dijelaskan oleh variabel lain diluar model. 


\section{Pengujian Signifikansi Secara Parsial}

Berdasarkan penerapan regresi data panel dengan metode Common Effect diperoleh hasil, secara parsial membuktikan Volume Penawaran Saham berpengaruh positif dan signifikan terhadap Risiko Sistematis (Y) yang ditunjukkan dari nilai probabilitasnya sebesar 0.0000 lebih kecil dari $\alpha=0.05$ atau t-hitung $=5.3814$ lebih besar $\mathrm{t}_{\text {-tabel }}(\alpha, \mathrm{n}-\mathrm{k}: 5 \%, 80-2)=1.664$.

Pembahasan. Pengajuan hipotesis dalam penelitian ini yaitu volume penawaran saham berpengaruh positif terhadap risiko sistematis. Dari pengujian secara statistik diperoleh hasil volume penawaran saham berpengaruh positif dan signifikan terhadap risiko sistematis, maka hipotesis diterima. Seperti teori yang ungkap oleh Umam dan Sutanto (2017), harga saham akan meningkat jika suatu saham berlebihan permintaannya dibandingkan penawaran, dan akan turun jika terjadi penawaran yang berlebihan. Ang (2010) mengemukakan, frekuensi perdagangan yang meningkat akan memengaruhi aktivitas pasar dalam perdagangan, dan akan berakibat harga saham berfluktuasi naik atau turun, sehingga berdampak meningkatnya volatilitas harga saham. Chan dan Fong (2000) juga mengungkapkan, apabila volume perdagangan meningkat maka volatilitasnya juga akan naik. Harga saham berfluktuasi menyebabkan meningkatnya risiko sistematis.

Temuan penelitian ini menunjukkan bukti bahwa volume penawaran saham berpengaruh positif dan signifikan terhadap risiko sistematis yang berarti naik turunnya volume penawaran saham akan berdampak naik turunnya risiko sistematis.

Temuan penelitian sesuai dengan teori hubungan antara volume penawaran saham dengan risiko sistematis, dimana risiko sistematis saham-saham dalam kelompok JII meningkat dampak dari terjadinya kelebihan penawaran volume saham. Kelebihan penawaran saham ini memberikan gambaran meningkatnya pemodal di bursa yang melepas atau menjual sahamnya dalam kondisi merebaknya virus corona. Rully R. Ramli (Kompas.com) mengutip pendapat OJK (12/03/2020), sentimen negatif sebagai salah satu penyebab penekan kinerja ekonomi global sejak Januari 2020 adalah karena virus corona. Sentimen negatif ini penyebab pemodal asing mencairkan dananya di pasar saham yang akhirnya menyebabkan penawaran volume saham yang berlebihan.

Rully lebih lanjut mengutip pendapat OJK : terdapat tiga faktor eksternal yang menekan pasar modal dunia, yakni pandemi virus corona, persaingan yang ketat harga minyak, dan penurunan the Fed Rate (suku bunga) yang dilakukan oleh Bank Sentral Amerika Serikat Federal Reserve. Lebih rinci OJK menguraikan sebagaimana dikutip oleh Rully sebagai berikut:

- Sejak awal tahun 2020 kinerja ekonomi global terus ketekan oleh sentimen negatif akibat merebaknya virus corona. Diperkirakan tekanan ini semakin kuat setelah pengumuman status virus corona sebagai pandemi global yang dikeluarkan oleh setelah Organisasi Kesehatan Dunia (WHO).

- Selanjutnya, persaingan harga minyak dunia yang ketat antara Rusia dan Arab Saudi yang menambah semakin meningkatnya ketidakpastian perekonomian global. "Kedua yang kita hadapi sekarang adalah persaingan harga minyak yang telah mencapai 30 dollar AS per barrel. Arab Saudi pada akhirnya membalas yang sekarang liftingnya 12,3 juta barel per hari dan itu 20 kali lipat lifting Indonesia." 
- Terakhir, The Fed memutuskan untuk menurunkan suku bunga sebesar 50 basis poin menjadi 1,00 sampai 1,25 persen akibat mewabahnya Covid-19, diangap belum efektif berdampak terhadap perekonomian global.

Hasil penelitian ini juga mendukung temuan penelitian terdahulu dalam kondisi normal (diluar pandemi Covid-19) seperti yang dilakukan oleh Tara (2018), Rizqin dan Mohammad (2017), Dewi dan Suaryana (2016), Sandrasari (2010) yang dihasilkan temuan volume perdagangan saham berpengaruh positif dan signifikan terhadap volatilitas harga saham.

\section{SIMPULAN DAN KETERBATASAN}

Simpulan. Tujuan dari penelitian ini untuk mengetahui dampak volume penawaran saham terhadap risiko sistematis pada kondisi merebaknya virus Covid-19 dengan obyek penelitian pada saham-saham dalam kelompok Jakarta Islamic Index di Bursa Efek Indonesia dengan menggunakan metode analisis regresi data panel metode common effect. Data panel yang mengkombinasi data time series 4 periode pengamatan dari Januari 2020 hingga April 2020, dan data cross section dengan 20 saham sebagai sampel penelitian. Penelitian ini menemukan hasil volume penawaran saham berpengaruh positif dan signifikan terhadap risiko sistematis saham-saham dalam kelompok Jakarta Islamic Index di BEI pada kondisi pandemi virus Covid-19.

Keterbatasan dan Saran. Dalam rangka untuk memperluas hasil penelitian ini, maka penelitian selanjutnya dapat mempertimbangkan variabel lain seperti The Fed Rate, indeks-indeks dunia yang diduga dapat memengaruhi Risiko Sistematis dalam kondisi Pandemi Covid-19. Obyek penelitian ini hanya sebatas pada saham-saham dalam kelompok JII, maka untuk penelitian selanjutnya dapat melakukan penelitian per sektor industri, saham-saham dalam kelompok indeks lainnya. Metode analisis regresi data panel yang digunakan dalam penelitian ini adalah metode common effect, untuk penelitian selanjutnya dapat mempertimbangkan metode fixed effect atau random effect.

\section{REFERENSI}

Ang Robert.2010. Buku Pintar Pasar Modal Indonesia. Media Staff. Jakarta

Bank Indonesia

Bursa Efek Indonesia (BEI)

Chan,K. dan W.M. Fong. 2000. Trade size, Order Imbalance, and The Volatility Volume Relation. Journal of Financial Economics. p. $248-249$

CNBC Indonesia

CNN Indonesia

Dewi, N. M. A. K., \& Suaryana, I. G. N. A. (2016). Pengaruh Volume Perdagangan Saham, Leverage, dan Tingkat Suku Bunga Terhadap Volatilitas Harga Saham. EJurnal Akuntansi Universitas Udayana, 17(2), 1112-1140 
Fahmi, Irham. 2014. Manajemen Keuangan Perusahaan Dan Pasar Modal. Mitra Wacana Media. Jakarta

Ghozali, Imam. 2014. Ekonometrika Teori, Konsep dan Aplikasi dengan IBM SPSS 22, Universitas Diponegoro. Semarang

Husnan, Suad. 2005. Dasar-dasar Teori Portofolio dan Analisis Sekuritas. Edisi kelima. BPFE. Yogyakarta

IndoPremier (www.indopremier.com)

IDX Chanel.Com

Investing.com

Jogiyanto, Hartono. 2017. Teori Portofolio dan Analisis Investasi. Edisi kesepuluh, BPFE. Yogyakarta

Keown Arthur J, Martin John D, Petty William, Scott, JR. 2004. Financial Management : Priciples and Application (Manajemen Keuangan : Prinsip-Prinsip dan Aplikasi), Edisi Kesembilan, Prentice Hall. Edisi Indonesia Penerbit PT Indeks. Jakarta

Laura Laube and Kārlis Malcenieks.2013. The Impact of High Frequency Trading: Systematic Risk in European Equity Markets. (Diunduh 13 Mei 2020). https://pdfs.semanticscholar.org

Nidal Rashid Sabri. 2008. The Impact of Trading Volume on Stock Price Volatility in the Arab Economy. Journal of Derivatives \& Hedge Funds 14(3-4) June 2008

Pengumuman BEI No Peng-00555/BEI.POP/11-2019

Peraturan OJK Nomor 17/POJK.04/2015 tentang Penerbitan dan Persyaratan Efek Syariah Berupa Saham oleh Emiten Syariah atau Perusahaan Publik Syariah

Peraturan OJK Nomor 35/POJK.04/2017 tentang Kriteria dan Penerbitan Daftar Efek Syariah

Rahmawati.2017. Pengaruh Volume Perdagangan, Devidend Payout Ratio, Inflasi terhadap Volatlilitas Harga Saham Pada Perusahaan yang terdaftar dalam Indeks LQ45 tahun 2011-2015. Jurnal Pendidikan dan Ekonomi, Vol. 6, Nomor 1, Hal: $38-45$

Rizqin Mobarak dan Mohammad Kholiq Mahfud. 2017. Analisis Pengaruh Kebijakan Dividen, BVPS, Earning Volatility, Leverage, PER, dan Volume Perdagangan terhadap Volatilitas Harga Saham (Studi Empiris Pada Perusahaan Go Public Non Keuangan Yang Listing di Bursa Efek Indonesia Tahun 2012-2015). DIPONEGORO JOURNAL OF MANAGEMENT Volume 6, Nomor 2, Tahun 2017, Halaman 1-13

Sandrasari. 2010. Analisis Pengaruh Volume Perdagangan, Frekuensi Perdagangan, dan Order Imbalance Terhadap Volatilitas Harga Saham Pada Perusahaan Go Public di Bursa Efek Indonesia. Universitas Sebelas Maret

Schwert, G. William. 1989. "Why Does Stock Market Volatility Change Over Time?". The Journal Of Finance Vol. XLIV, No. 5

Sharpe, William F., Alexander. Gordon J., Bailey, Jeffrey V. 2005. Investasi. Edisi 6. Indeks Jakarta 
Sunariyah. 2013. Pengantar Pengetahuan Pasar Modal. Edisi Keenam, UPP STIM YKPN. Yogyakarta

Syarifah Nur Azura, Myrna Sofia dan Nurhasanah. 2018. Faktor -Faktor yang Mempengaruhi Volatilitas Harga Saham pada Perusahaan Manufaktur yang Tercatat di Bursa Efek Indonesia Tahun 2012-2016. (Diunduh 13 Mei 2020) http://repository.umrah.ac.id.

Syamsir, Hendra. 2006. Solusi Investasi di Bursa Saham Indonesia Pendekatan Analisis Teknikal melalui Studi Kasus Riil dengan Dilengkapi Formulasi MetaStock. Elex Media Komputindo. Jakarta

Tara Widiarti S. 2018. Faktor-Faktor Yang Mempengaruhi Volatilitas Harga Saham pada Perusahaan Yang Terdaftar di Indeks LQ 45. (Diunduh 13 Mei 2020). http://eprints.perbanas.ac.id/ 3838/8/ARTIKEL\%20ILMIAH.pdf

Tandelilin, Eduardus. 2010. Portofolio dan Analisis Investasi Teori dan Aplikasi, Edisi Pertama. Kanisius. Yogyakarta

Tim Studi Volatilitas Pasar Modal Indonesia dan Perekonomian Dunia, Laporan Studi Volatilitas Pasar Modal Indonesia Dan Perekonomian Dunia. (Jakarta: Kementerian Keuangan Republik Indonesia Badan Pengawas Pasar Modal Dan Lembaga Keuangan, 2011), hal. 8-10

Umam, Khaerul dan Sutanto, Herry. 2017. Manajemen Investasi. Pustaka Setia. Bandung 